\title{
LITERASI MAHASISWA PROGRAM STUDI TADRIS KIMIA TERHADAP UNDANG-UNDANG NO. 33 TAHUN 2014 TENTANG JAMINAN PRODUK HALAL
}

\author{
Ardian Trio Wicaksono \\ Program Studi Tadris Kimia, Fakultas Tarbiyah dan Keguruan, Universitas Islam Negeri Antasari \\ ardian.tw@uin-antasari.ac.id
}

Trining Puji Astutik

Program Studi Tadris Kimia, Fakultas Tarbiyah dan Keguruan, Universitas Islam Negeri Antasari ningtut@gmail.com

\begin{abstract}
Abstrak
Undang Undang No 33 tahun 2014 tentang Jaminan Produk Halal (JPH) yang disahkan tanggal 17 Oktober 2014 merupakan instrumen penting untuk menjamin kepastian hukum penyelenggaraan jaminan produk halal di Indonesia. Salah satunya adalah MUI memiliki kewenangan melakukan sertifikasi auditor halal, penetapan fatwa kehalalan produk serta akreditasi lembaga pemeriksa halal. Persyaratan menjadi auditor halal pasal 14 ayat 2c adalah berpendidikan paling rendah sarjana strata 1 di bidang pangan, kimia, biokimia, teknik industri, biologi, atau farmasi. Berdasarkan persyaratan tersebut maka Program Studi Tadris Kimia FTK UIN Antasari yang mencetak dan menghasilkan lulusan sarjana strata 1 di bidang pendidikan kimia yang didalamnya juga mengajarkan kimia dan biokimia memiliki kesempatan menjadi auditor halal. Hal ini menjadi tantangan tersendiri bagi mahasiswa Prodi Tadris Kimia untuk membaca UU tersebut dan mengikuti perkembangan jaman. Tujuan dari penelitian ini mengetahui literasi mahasiswa Prodi Tadris Kimia dalam membaca UU JPH dan faktor faktor yang mempengaruhinya. Jenis penelitian yang dilakukan adalah penelitian lapangan mengunakan pendekatan kualititatif. Teknik pengumpulan data dilakukan melalui angket dan dokumenter. Hasil penelitian menunjukkan bahwa Literasi Mahasiswa Prodi Tadris Kimia terhadap UU JPH masih rendah. Faktor yang mempengaruhi Literasi Mahasiswa Prodi Tadris Kimia terhadap UU JPH adalah faktor intrinsik dan faktor ekstrinsik.
\end{abstract}

Kata Kunci: Literasi, Mahasiswa Tadris Kimia, Jaminan Produk Halal.

\begin{abstract}
Law No. 33 of 2014 concerning Halal Product Guarantee (JPH) which was passed on October 17,2014 is an important instrument to guarantee legal certainty in the implementation of halal product guarantee in Indonesia. One of them is that the MUI has the authority to certify halal auditors, the stipulation of halal fatwas and the accreditation of halal examiners. Requirements to become a halal auditor article 14 paragraph 2c is the least educated bachelor degree in food, chemistry, biochemistry, industrial engineering, biology, or pharmacy. Based on these requirements, the Tadris Chemistry Study Program of FTK UIN Antasari, which produces and produces undergraduate graduates in chemical education, which also teaches chemistry and biochemistry has the opportunity to become halal auditors. This has become a challenge for students of Tadris Chemistry Study Program to read the Act and follow the changing times. The purpose of this study is to find out the literacy of Tadris Kimia Study Program students in reading the JPH Law and the factors that influence it. This type of research is field research using a qualitative approach. Data collection techniques carried out through questionnaires and documentaries. The results showed that the Literacy of Tadris Chemistry Study Program Students in the JPH Law was still low. Factors that influence Literacy of Tadris Chemistry Study Program to JPH Law are intrinsic and extrinsic factors.
\end{abstract}

Keywords: Literacy, Tadris Chemistry Students, Halal Product Guarantee.

\section{PENDAHULUAN}

Indonesia merupakan negara dengan jumlah populasi muslim terbesar, hal ini mengakibatkan permintaan makanan halal meningkat. Dengan perkembangan jaman, kesadaran masyarakat untuk menggunakan 
dan mengkonsumsi produk halal juga meningkat. Perkembangan jaman ini tentunya diikuti oleh perkembangan teknologi yang menumbuhkan munculnya berbagai macam produk olahan. Produk olahan ini tidak hanya dari dalam negeri tetapi juga produk-produk olahan luar negeri juga memenuhi pasar Indonesia. Produkproduk olahan baru yang belum diketahui kehalalannya, sebagai dampaknya mengkonsumsi produk halal merupakan hal yang sangat penting karena menjadi bagian dari kesempurnaan syariat Islam. Hal ini sesuai terjemahan Q.S. Al-Baqarah (2): 168 yang berbunyi: "Wahai manusia! Makanlah dari (makanan) yang halal dan baik yang terdapat di bumi, dan janganlah kamu mengikuti langkah-langkah setan. Sungguh, setan itu musuh yang nyata bagimu". Allah menyuruh hamba-Nya yang beriman memakan yang baik-baik dari rezeki yang telah dianugerahkan kepada mereka. Oleh karena itu, hendaklah mereka bersyukur kepada-Nya jika mereka mengaku sebagai hamba-Nya. Memakan makanan halal merupakan sarana untuk diterimanya do'a dan ibadah (Kasdi, 2013).

Berdasarkan ayat di atas menjadi suatu pertimbangan untuk umat muslim dalam membeli atau mengkonsumsi produk pangan baik berupa makanan dan minuman. Jika suatu makanan atau minuman jelas kehalalannya seperti yang tertera dalam Alquran, konsumen muslim tenang dalam menikmati dan mengkonsumsinya. Sebaliknya, ketika suatu produk pangan sudah diolah dengan teknologi yang canggih, maka konsumen muslim dituntut untuk lebih selektif dalam memilih produk yang dikonsumsi. Hal ini karena di era ilmu pengetahuan dan teknologi yang semakin maju ini, kehalalan produk pangan tidak dapat ditentukan secara manual dan sederhana, namun diperlukan proses pengujian yang juga menggunakan ilmu pengetahuan dan teknologi tertentu. Oleh karena itu, perlu adanya lembaga yang dapat menjamin kehalalan produk-produk yang dikonsumsi dan beredar di Indonesia.

Majelis Ulama Indonesia (MUI) berdiri pada tanggal 26 Juli 1975, sebagai hasil dari pertemuan atau musyawarah para ulama, cendikiawan dan zu'ama yang datang dari penjuru tanah air, antara lain meliputi 26 provinsi di Indonesia pada masa itu (Habibaty, 2017). MUI melalui Lembaga Pengkajian Pangan, Obat-obatan, dan Kosmetika Majelis Ulama Indonesia (LPPOM MUI) melakukan penelitian, mengkaji, menganalisis dan memutuskan terkait keamanan, kesehatan, dan kehalalan terhadap produk-produk pangan dan turunannya, obat-obatan dan produk kosmetika yang dikonsumsi umat muslim khususnya di Indonesia. LPPOM MUI juga memberikan rekomendasi, merumuskan ketentuan dan bimbingan kepada layanan masyarakat. MUI dan LPPOM MUI sebagai lembaga independen yang selama ini telah memperjuangkan kehalalan produk yang beredar di Indonesia perlu diperkuat oleh negara melalui suatu regulasi yang khusus mengatur tentang ketentuan produk halal. Salah satunya adalah MUI memiliki kewenangan untuk melakukan sertifikasi auditor halal, penetapan fatwa kehalalan produk serta akreditasi lembaga pemeriksa halal.

Sertifikasi auditor halal merupakan pengakuan terhadap kompetensi atau kemampuan yang dimiliki oleh seorang auditor dalam menangani bidang yang dikerjakan dan dibuktikan dengan Sertifikat Kompetensi. Seseorang dapat menjadi auditor halal bila memenuhi persyaratan sesuai yang tercantum dalam UU No 33 tahun 2014 tentang Jaminan Produk Halal pasal 14 ayat 2: (a) warga negara Indonesia, (b) beragama Islam, (c) berpendidikan paling rendah sarjana strata 1 (satu) di bidang pangan, kimia, biokimia, teknik industri, biologi, atau farmasi, (d) memahami dan memiliki wawasan luas mengenai kehalalan produk menurut syariat islam, (e) mendahulukan kepentingan umat di atas kepentingan pribadi dan/atau golongan, dan (f) memperoleh sertifikat dari MUI.

Persyaratan untuk menjadi auditor halal pada pasal 14 ayat $2 \mathrm{c}$ adalah berpendidikan paling rendah sarjana strata 1 (satu) di bidang pangan, kimia, biokimia, teknik industri, biologi, atau farmasi. Berdasarkan persyaratan tersebut maka Program Studi (Prodi) Tadris Kimia Fakultas Tarbiyah dan Keguruan (FTK) UIN Antasari Banjarmasin 
sebagai Lembaga Pendidikan Tinggi. Prodi Tadris Kimia mencetak dan menghasilkan lulusan sarjana strata 1 (satu) di bidang pendidikan kimia yang didalamnya juga mengajarkan kimia dan biokimia memiliki kesempatan untuk menjadi auditor halal. Auditor halal merupakan salah satu peluang profesi yang sesuai untuk alumni Prodi Tadris Kimia FTK UIN Antasari Banjarmasin.

Terhitung hampir 5 (lima) tahun sejak disahkannya UU No 33 tahun 2014 tentang Jaminan Produk Halal pada tanggal 17 Oktober 2014, literasi tentang produk halal berkembang pesat di era globalisasi dengan kecanggihan teknologi saat ini. Hal ini menjadi tantangan tersendiri bagi mahasiswa Prodi Tadris Kimia FTK UIN Antasari Banjarmasin dalam mengikuti perkembangan literasi tersebut.

Berbagai penelitian terkait kepastian hukum kehalalan produk pangan, pemahaman label halal serta penyelenggaraan jaminan produk halal telah dilakukan oleh peneliti peneliti sebelumya, antara lain: (1) Hasan (2014) menyimpulkan bahwa sertifikasi halal selama ini telah dilakukan oleh MUI melalui LPPOM MUI dan Komisi Fatwa. Labelisasi Halal yang dikelola oleh Badan POM sudah sangat tepat dan memberikan jaminan perlindungan dan kepastian hukum produk pangan halal karena sudah melalui proses yang panjang antara lain adanya sistem jaminan halal (SJH) oleh perusahaan, audit oleh LPPOM dan Komisi Fatwa, (2) Fatkhurohmah (2015) menyimpulkan bahwa terdapat pengaruh yang signifikan terkait pemahaman label halal dan faktor sosial terhadap niat membeli makanan kemasan berlabel halal pada santri mahasiswa pondok pesantren Al Barokah, (3) Saan (2018) menyimpulkan bahwa pelaksanaan Jaminan Produk Halal yang diamanatkan dalam UU JPH memerlukan dukungan politik, koordinasi dan sinergi kebijakan dari para pemangku kepentingan (stake holder). Sertifikasi halal diharapkan efektif dan massif menjangkau produk impor makanan, obat-obatan/farmasi dan kosmetika yang dijual di pasar-pasar swalayan dan tempat lainnya, (4) Aziz dan Wahab (2013) menyimpulkan bahwa terdapat hubungan yang signifikan antara sikap, norma subjektif, persepsi kontrol perilaku, pengetahuan, kemurnian dan keamanan terhadap niat seseorang dalam membeli kosmetik halal, (5) Hasil penelitian tersebut diperkuat oleh penelitian Lada dkk (2009) yang menunjukkan bahwa sikap dan norma subjektif berpengaruh terhadap niat seseorang dalam memilih berbagai produk yang halal, dan (6) Listyoningrum dan Albari (2012) juga menyimpulkan bahwa tidak masalah bagi perusahaan jika tidak melakukan perpanjangan sertifikat halal, tetapi karena produk BT ini beroperasi di Indonesia yang mayoritas penduduknya beragama Islam, alangkah baiknya jika perusahaan BT segara mengajukan dan memproses sertifikat halal yang baru ke MUI untuk dapat menjamin keamanan produk dan menjaga kesetiaan konsumen terutama konsumen muslim.

Beberapa penelitian tersebut secara spesifik belum membahas tentang literasi mahasiswa pada UU No. 33 tahun 2014 yang telah disahkan hampir 5 (lima) tahun yang lalu. Hal ini dapat dijadikan dasar untuk mengetahui literasi mahasiswa Prodi Tadris Kimia FTK UIN Antasari Banjarmasin terhadap Undang Undang No. 33 tahun 2014 tentang Jaminan Produk Halal.

Berdasarkan paparan-paparan tersebut, peneliti tertarik untuk mengadakan penelitian dengan judul: "Literasi Mahasiswa Program Studi Tadris Kimia Fakultas Tarbiyah dan Keguruan UIN Antasari Banjarmasin terhadap Undang Undang No. 33 tahun 2014 tentang Jaminan Produk Halal".

\section{METODE}

Jenis penelitian yang penulis lakukan adalah penelitian lapangan yang bertujuan untuk mengetahui literasi mahasiswa Prodi Tadris Kimia FTK UIN Antasari Banjarmasin dalam membaca Undang Undang No. 33 tahun 2014 tentang Jaminan Produk Halal dan faktor-faktor yang mempengaruhinya. Penelitian ini mengunakan pendekatan kualititatif yaitu menyampaikan fakta dan mendeskripsikannya.

Sumber data dalam penelitian ini adalah mahasiswa Prodi Tadris Kimia FTK UIN Antasari Banjarmasin angkatan 2017 yang 
berjumlah 9 (sembilan) orang dan angkatan 2018 yang berjumlah 17 (tujuh belas) orang sehingga total responden adalah 26 (dua puluh enam) orang. Teknik pengumpulan data dalam penelitian ini menggunakan beberapa teknik, yaitu: (1) angket, untuk mengetahui secara langsung literasi mahasiswa Prodi Tadris Kimia FTK UIN Antasari terhadap Undang Undang No. 33 tahun 2014 tentang Jaminan Produk Halal, dan (2) dokumenter, untuk menelaah berkas atau catatan penting yang berkaitan dengan data-data yang diperlukan.

Teknik analisis data yang digunakan dalam penelitian ini adalah teknik deskriptif kualitatif, melalui tahapan: reduksi, display dan verifikasi. Pada tahap reduksi diupayakan menemukan hal-hal pokok tentang literasi mahasiswa Prodi Tadris Kimia FTK UIN Antasari Banjarmasin terhadap Undang Undang No. 33 tahun 2014 tentang Jaminan Produk Halal dan faktor yang mempengaruhinya. Pada tahap display dilakukan perangkuman informasi dengan susunan yang sistematis, sehingga tema sentral yang berhubungan dengan literasi mahasiswa Prodi Tadris Kimia FTK UIN Antasari Banjarmasin terhadap Undang Undang No. 33 tahun 2014 tentang Jaminan Produk Halal dapat diketahui dengan mudah. Tahap berikutnya adalah tahapan verifikasi yakni dilakukan pemberian makna yang relevan atas kesimpulan yang diambil.

\section{HASIL DAN PEMBAHASAN}

\section{Literasi Mahasiswa Prodi Tadris Kimia FTK UIN Antasari Banjarmasin terhadap Undang Undang No. 33 tahun 2014 tentang Jaminan Produk Halal}

\footnotetext{
Istilah literasi secara sederhana dipahami sebagai kemampuan atau keterampilan membaca dan menulis. Membaca berarti mengeja lambanglambang bahasa hingga diperoleh sebuah pengertian. Menulis berarti mengungkapkan pemikiran dengan mengukirkan lambanglambang bahasa hingga membentuk sebuah pengertian (Damayantie, 2012). Literasi dalam penelitian ini adalah literasi mahasiswa Prodi Tadris Kimia FTK UIN Antasari Banjarmasin dalam membaca Undang Undang No. 33 tahun 2014 tentang
}

Jaminan Produk Halal. Hal ini perlu dilakukan karena mahasiswa Prodi Tadris Kimia erat kaitannya dengan berbagai pengetahuan terkait kehalalan suatu produk yang secara langsung telah ditempuh dalam perkuliahan melalui sebaran kurikulum.

Buku Kurikulum KKNI UIN Antasari Banjarmasin (Tim Penyusun, 2018) berisi deskripsi lengkap mata kuliah kimia yang berkaitan dengan Undang Undang No. 33 tahun 2014 dan Buku Pedoman Akademik Program S-1 Fakultas Tarbiyah dan Keguruan (Tim Penyusun, 2018:74-75) memuat sebaran mata kuliah Prodi Tadris Kimia yang erat kaitannya dengan literasi produk halal yang terdapat pada UU No. 33 Tahun 2014, yakni: (1) Kimia Dasar; (2) Kimia Organik; (3) Dasar Kimia Analitik; (4) Kimia Dasar Lanjut; (5) Ikatan Kimia; (6) Struktur Atom dan Kimia Unsur; (7) Termodinamika dan Kesetimbangan; (8) Praktikum Dasar Kimia Analitik; (9) Praktikum Kimia Dasar Lanjut; (10) Manajemen Laboratorium Kimia; (11) Struktur dan Reaktivitas Senyawa Anorganik; (12) Kinetika Kimia; (13) Kimia Pemisahan; (14) Praktikum Kimia Pemisahan; dan (15) Praktikum Kimia Organik. Sedikit berbeda dengan angkatan 2017, mahasiswa Prodi Tadris Kimia angkatan 2018 telah menempuh beberapa mata kuliah yang erat kaitannya dengan literasi produk halal yang terdapat pada UU No. 33 Tahun 2014, yakni: (1) Kimia Dasar; (2) Praktikum Kimia Dasar; (3) Kimia Organik; (4) Dasar Kimia Analitik; (5) Kimia Dasar Lanjut; (6) Ikatan Kimia; (7) Struktur Atom dan Kimia Unsur; (8) Termodinamika dan Kesetimbangan; (9) Praktikum Dasar Kimia Analitik; dan (10) Praktikum Kimia Dasar Lanjut.

Mata kuliah yang erat kaitannya dengan literasi produk halal yang terdapat pada UU No. 33 Tahun 2014 terdiri atas mata kuliah yang bersifat teori dan mata kuliah yang bersifat praktikum sesuai dengan kebutuhan dan nama mata kuliah tersebut. Mata kuliah tersebut berisi materi materi yang dapat menunjang pengetahuan mahasiswa terkait kimia yang secara khusus berhubungan dengan literasi produk halal yang terdapat pada UU No. 33 Tahun 2014. Penyebaran angket kepada mahasiswa dilakukan dengan 
memberikan pertanyaan: Apakah Anda pernah membaca Undang Undang No. 33 Tahun 2014 tentang Jaminan Produk Halal? Jelaskan faktor faktor yang mempengaruhi jawaban Anda! Berikut data terkait hasil penyebaran angket dalam Tabel 1 .

Tabel 1. Hasil Penyebaran Angket Literasi Mahasiswa

\begin{tabular}{|l|c|}
\hline $\begin{array}{l}\text { Pernah membaca UU No. 33 } \\
\text { Tahun 2014 }\end{array}$ & 8 \\
\hline $\begin{array}{l}\text { Tidak pernah membaca UU No. 33 } \\
\text { Tahun 2014 }\end{array}$ & 18 \\
\hline \multicolumn{1}{|c|}{ Jumlah } & 26 \\
\hline
\end{tabular}

Berdasarkan Tabel 1 dapat dilihat bahwa 8 mahasiswa pernah membaca Undang Undang No. 33 tahun 2014 tentang Jaminan Produk Halal dan 18 mahasiswa tidak pernah membaca Undang Undang No. 33 tahun 2014 tentang Jaminan Produk. Berikut juga kami sajikan besaran persentase dalam diagram pie.

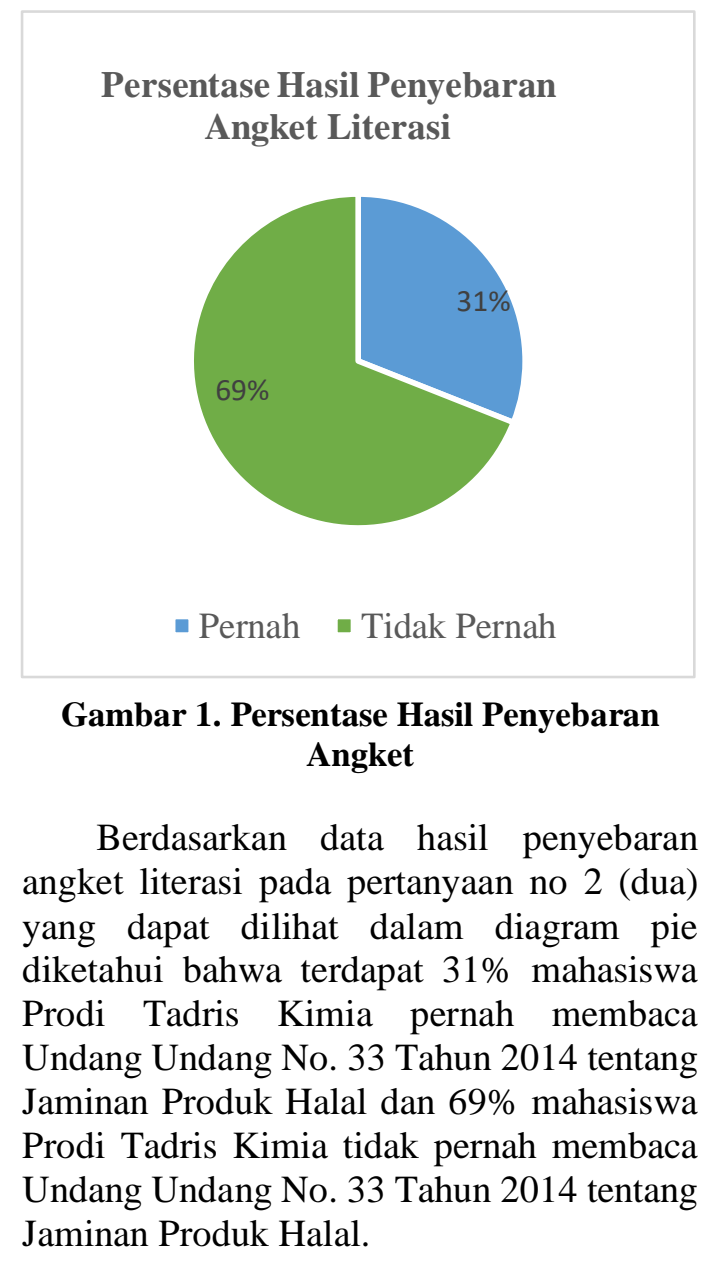

Faktor Faktor yang Mempengaruhi Literasi Mahasiswa Prodi Tadris Kimia FTK UIN Antasari Banjarmasin terhadap Undang Undang No. 33 tahun 2014 tentang Jaminan Produk Halal

Banyak faktor yang dapat mempengaruhi literasi seorang mahasiswa. Terdapat 5 (lima) faktor yang mempengaruhi minat baca mahasiswa, yakni: (1) keadaan lingkungan sosial yang kondusif; (2) rasa ingin tahu yang tinggi atas fakta, teori, prinsip, pengetahuan, dan informasi; (3) keadaan lingkungan fisik yang memadai; (4) rasa haus informasi dan rasa ingin tahu; dan (5) prinsip hidup bahwa membaca merupakan kebutuhan rohani (Anugra dkk, 2013). Hasil penelitian tersebut juga sesuai dengan penelitian yang dilakukan Amalia dan Siregar yang menyimpulkan bahwa faktor-faktor yang mempengaruhi masyarakat kota Medan dalam keliterasian membaca bahasa Indonesia yang berkemajuan adalah faktor rasa ingin tahu yang tinggi atas fakta, teori, prinsip, pengetahuan dan informasi (Amalia dan Siregar, 2018). Berdasarkan beberapa penelitian tersebut dapat diketahui bahwa banyak faktor yang dapat mempengaruhi literasi mahasiswa. Oleh karena itu, faktor faktor yang mempengaruhi literasi mahasiswa dalam penelitian ini yang diperoleh melalui penyebaran angket lebih disederhanakan menjadi 2 (dua) faktor yakni faktor intrinsik dan faktor ekstrinsik. Dimyati dan Mudjiono menyatakan bahwa faktor intrinsik adalah faktor pendorong dalam diri (internal) individu, sedangkan faktor ekstrinsik adalah faktor yang terjadi akibat adanya pengaruh rangsangan dari luar (eksternal) individu (Dimyati dan Mudjiono, 2006).

Faktor faktor intrinsik yang mempengaruhi literasi mahasiswa Prodi Tadris Kimia FTK UIN Antasari Banjarmasin terkait Undang Undang No. 33 tahun 2014 tentang Jaminan Produk Halal adalah: (1) Mahasiswa belum pernah belajar Undang Undang No. 33 Tahun 2014 tentang Jaminan Produk Halal, hanya mengetahui dari pembelajaran agama seperti fikih tentang makanan yang halal dan haram untuk dikonsumsi, (2) Mahasiswa kurang 
mengetahui tentang Undang Undang No. 33 tahun 2014 tentang Jaminan Produk Halal, (3) Mahasiswa tidak pernah memiliki niat mencari tahu Undang Undang No. 33 tahun 2014 tentang Jaminan Produk Halal, (4) Mahasiswa tidak pernah membaca Undang Undang, dan (5) Mahasiswa tidak mengetahui bahwa terdapat Undang Undang No. 33 tahun 2014 tentang Jaminan Produk Halal.

Faktor faktor ekstrinsik yang mempengaruhi literasi mahasiswa Prodi Tadris Kimia FTK UIN Antasari Banjarmasin terkait Undang Undang No. 33 tahun 2014 tentang Jaminan Produk Halal adalah: (1) Undang Undang No. 33 Tahun 2014 tidak pernah di bahas di sekolah, (2) Undang Undang No. 33 Tahun 2014 tidak kontroversi/viral di media sosial, (3) Mahasiswa tidak menemukan artikel atau buku terkait Undang Undang No. 33 tahun 2014 tentang Jaminan Produk Halal, dan (4) Tidak ada peraturan terkait/perintah yang mengharuskan membaca Undang Undang No. 33 tahun 2014 tentang Jaminan Produk Halal.

\section{DAFTAR PUSTAKA}

Amalia Nadra dan Siregar Alfitriani. "Faktor-Faktor yang Mempengaruhi Literasi Membaca Bahasa Indonesia yang Berkemajuan". Prosiding Pekan Seminar Nasional (Pesona), (2018. https://journal.uhamka.ac.id (diakses pada tanggal 19 September 2019).

Anugra Helzi, Yusup M. Pawit, Erwina Wina. "Faktor-faktor yang Mempengaruhi Minat Baca Mahasiswa (Survei Eksplanatori tentang Minat Baca Mahasiswa di UPT Perpustakaan ITB)". Jurnal Kajian Informasi dan perpustakaan 1, No.2 (2013):137-145. https://jurnal.unpad.ac.id (diakses pada tanggal 17 September 2019).

Aziz, Noreen Noor Abdul dan Wahab, Eta. "Understanding of Halal Cosmetics Products: TPB Model", In: 1st FPTP Postgraduate Seminar 2013, Fakulti Pengurusan Teknologi dan Perniagaan, UTHM, (2013): 5. https://core.ac.uk (diakses pada tanggal 20 Oktober 2019).

\section{SIMPULAN}

Berdasarkan hasil penelitian dan pembahasan, maka diperoleh simpulan sebagai berikut: (1) Literasi Mahasiswa Prodi Tadris Kimia FTK UIN Antasari Banjarmasin terhadap Undang Undang No. 33 tahun 2014 tentang Jaminan Produk Halal masih tergolong rendah, dan (2) Faktorfaktor yang mempengaruhi Literasi Mahasiswa Prodi Tadris Kimia FTK UIN Antasari Banjarmasin terhadap Undang Undang No. 33 tahun 2014 tentang Jaminan Produk Halal meliputi faktor intrinsik (tidak ada keinginan dan motivasi mahasiswa mencari literatur tentang jaminan produk halal) dan faktor ekstrinsik (materi tidak dibahas pada tingkat pendidikan formal, Undang Undang No. 33 Tahun 2014 tidak kontroversi/viral di media sosial, Tidak ada peraturan terkait/perintah yang mengharuskan membaca Undang Undang No. 33 tahun 2014 tentang Jaminan Produk Halal).

Damayantie, Augustia Rahma. "Literasi dari Era ke Era". Journal Upgris, (2018): 3. http://journal.upgris.ac.id (diakses pada tanggal 25 Oktoer 2019).

Dimyati dan Mudjiono. 2006. Belajar dan Pembelajaran. Jakarta: Rineka Cipta.

Fatkhurohmah. "Pengaruh Pemahaman Label Halal dan Faktor Sosial terhadap Niat Membeli Produk Makanan Kemasan Berlabel Halal (Studi pada Santri Mahasiswa Pondok Pesantren Al Barokah)". Skripsi Program Studi Pendidikan Ekonomi Fakultas Ekonomi Universitas Negeri Yogyakarta, (2015): 129. https://eprints.uny.ac.id (diakses pada tanggal 18 Juni 2019).

Habibaty, Diana Mutia, "Peranan Fatwa Dewan Syariah Nasional -Majelis Ulama Indonesia terhadap Hukum Positif Indonesia", Jurnal Legislasi Indonesia 14, No. 04 (2017): 447-454. http://e-jurnal.peraturan.go.id (diakses pada tanggal 25 Oktober 2019).

Kasdi, Abdurrohman. "Tafsir Ayat-Ayat Konsumsi dan Implikasinya terhadap 
Pengembangan Ekonomi Islam". Jurnal Equilibrium 1, No.1 (2013): 21. http://journal.stainkudus.ac.id (diakses pada tanggal 25 Oktober 2019).

Hasan, KN. Sofyan. "Kepastian Hukum Sertifikasi dan Labelisasi Halal Produk Pangan". Jurnal Dinamika Hukum 1, No. 2 (2014): 237. www.dinamikahukum.fh.unsoed.ac.id (diakses pada tanggal 19 Juni 2019).

Lada, Suddin; Tanakinjal, Geoffrey Harvey dan Amin Hanudin. "Predicting intention to choose halal products using theory of reasoned action". International Journal of Islamic and Middle Eastern Finance and Management 2, No. 1 (2009): 66-76. www.emeraldinsight.com/17538394.htm (diakses pada tanggal 19 Oktober 2019).

Listyoningrum, Anggit dan Albari. "Analisis Minat Beli Konsumen Muslim terhadap Produk yang Tidak Diperpanjang Sertifikat Halalnya", Jurnal Ekonomi dan Keuangan Islam 2, No. 1 (2012): 40-51. https://journal.uii.ac.id (diakses pada tanggal 20 Oktober 2019).
Saan. "Penyelenggaraan Jaminan Produk Halal Berdasarkan Undang-Undang Republik Indonesia Nomor 33 Tahun 2014 Tentang Jaminan Produk Halal”. Jurnal Hukum Replik 6, No. 1 (2018): 65. http://jurnal.umt.ac.id (diakses pada tanggal 20 Juni 2019).

Tim Penyusun. Buku Kurikulum Kerangka Kualifikasi Nasional Indonesia Universitas Islam Negeri Antasari Banjarmasin. Banjarmasin: Bagian Akademik dan Kemahasiswaan, 2018.

Tim Penyusun. Buku Pedoman Akademik Program Sarjana (S-1) Fakultas Tarbiyah dan Keguruan. Banjarmasin: Fakultas Tarbiyah dan Keguruan, 2018.

Undang Undang Republik Indonesia Nomor 33 Tahun 2014 tentang Jaminan Produk Halal. Jakarta: Badan Penyelenggara Jaminan Produk Halal Kementerian Agama Republik Indonesia, 2018. 